\title{
QUANTITATIVE AND QUALITATIVE DETERMINATION OF ENROFLOXACIN RESIDUES IN FISH
} TISSUES

\author{
ĐORĐEVIĆ VESNA*, BALTIĆ $M^{* * *}$, ĆIRKOVIĆ $M^{* * *}$, KILIBARDA NATAŠA****, \\ GLAMOČLIJA NATAŠA ${ }^{* \star}$, STEFANOVIĆ $S^{*}$ and MIŠČEVIĆ MIRJANA***** \\ *Institute of Meat Higiene and Tehnology, Belgrade; **Faculty of Veterinary Medicine, University of

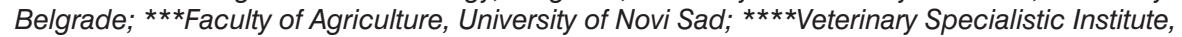 \\ Subotica; $* * \star \star S e r b i a n$ Chamber of Commerce \\ (Received $8^{\text {th }}$ March 2009)
}

Presence of enrofloxacin residues in fish liver, kidney and muscle tissue was investigated after per os application of the drug. For the purpose of determination of enrofloxacin, the following analytical methods were used: microbiological method - plate $\mathrm{pH} 8$ with Escherichia coli ATCC 11303 and HPLC method with fluorescence detection. After a 5-day oral treatment of carps, enrofloxacin residues in tissues were determined up to the 10th day after the end of the drug application. Enrofloxacin content determined by the HPLC method was lower than MRL; drug residues were determined in liver on the 6th day after treatment, in kidney on the 7th day and in muscle on the 9th day after treatment. The results of enrofloxacin residues determination by screening method on the medium with E. Coli ATCC 11303, pH 8 show that this procedure can be used for qualitative determination of enrofloxacin. The screening method allows determination of enrofloxacin in fish tissues below the MRL. Cyprofloxacin was not detected in fish liver, kidney and muscle tissue.

Key words: fish (carp), enrofloxacin, HPLC, microbiological methods, residues

\section{INTRODUCTION}

International trade in aquaculture has been growing continously in the recent years, and is expected to persist in the future. The variety of farmed aquatic species is now diversifying and fish farming is intensifying.

At the same time, increased incidence of disease, also due to intensive aquaculture, requires a more intense use of veterinary drugs and chemicals (Alderman, 1988; Baggot, 1977). Nonetheless, relatively few drugs have been approved for use in aquaculture, so fish farmers might use unapproved or unidentified active substances.

The use of antibiotics and chemotherapeutic agents in animals intended for human consumption should be based on toxicological and pharmacokinetic data 
obtained for specific animal species considered. However, the present knowledge of antibacterial drug pharmacokinetics in differenet fish species is very poor. Most data on pharmacokinetics of fluoroquinolones refers to their application in aquaculture of salmon and trout while the data on pharmacokinetics in carp are practically unavailable (Lucchetti et al., 2004). The availability of adequate data on the pharmacokinetics and bioavailabilities of antibacterial drugs in farmed fish is also important in order to minimize the environmental impact of the drugs used in aquaculture.

Quinolones are effective antibacterial drugs widely used both in human and in veterinary medicine for the treatment of various systemic bacterial infections (Brown, 1996; Ihrke et al., 1999; Tandriole, 1998).

During the last few years enrofloxacin, a molecule belonging to the quinolone antimicrobial family, has received growing attention because of its potential efficiency for the treatment of diseases in fish (Bragg et al., 1988; Dalsgaad et al., 1991; Brown, 1996; Burka et al., 1997; Lewbart et al., 1997; Stoffegren et al., 1997; Della Rocca et al., 2004). This drug is fluorinated quinolone carboxylic acid derivative, and it has been extensively used in veterinary medicine because of its broad activity spectrum (Drlica, 1999). In mammalian and nonmammalian species, enrofloxacin is metabolised to ciprofloxacin, a metabolite that contributes to the activity of enrofloxacin and which is itself a potent antimicrobial agent. Some microbiological metabolic and pharmacokinetic aspects of enrofloxacin have been reported from previous studies on fish (Bowser et al., 1990, Bowser et al., 1992; Martinses et al., 1995; Lewbart. et al., 1997; Stoffegren et al., 1997; Intorre et al., 2000; Della Rocca et al., 2004). However, very few data on enrofloxacin depletion in fishes reared under field conditions are available (Della Rocca et al., 2004; Steffenak et al., 1991).

Depletion of drugs in fish must be assessed in order to determine the time needed before the antibiotic is eliminated from animal tissue and to assess in a definite way when the treated animal can be safely consumed.

The commission of the European Union establishes and periodically reviews veterinery drugs maximum residue levels (MRL) in food. MRL is defined (European Economic Commission, 2002) as the maximum concentration of residue resulting from the use of a veterinary medicinal product (expressed in milligrams per kilogram of body weight or micrograms per kilogram on a fresh weight basis), that may be accepted by the European Union to be legally permitted or recognized in or on food. It is based on the type or amount of residue considered to be without any toxicological hazard for human health, expressed as the acceptable daily intake (ADI), or is based on temporary ADI values that use an additional safety factor. It also takes into account other relevant public health risks, as well as food technology aspects. The Commission of the European Union has established MRL of $100 \mu \mathrm{g} / \mathrm{kg}^{-1}$ as the sum of the levels of enrofloxacin and ciprofloxacin in tissue (muscle plus skin in natural proportions) from fishes in general (European Economic Commission, 2002).

The aim of this paper is to investigate enrofloxacin residues in carp tissues (liver, kidney, muscle tissue) after a five-day oral application of the drug in therapeutic doses. Two analytical methods were applied for the purpose of 
investigation, microbiological (screening) method and high performance liquid chromatographic (HPLC) method with fluorescence detection.

\section{MATERIALS AND METHODS}

The experiment was carried out on 100 carps (Cyprinus carpio), body weight of $300 \pm 50 \mathrm{~g}$. Carps were taken from the same fish pond and kept in basins with well water. Water temperature in the basins was maintained at $22 \pm 1^{\circ} \mathrm{C}$ by the use of heaters with thermostats and the temperature was recorded twice a day. Fish were fed with complete extruded pelleted feed (25\% proteins, $8 \%$ fat) regularly used at the fish pond. Fish were fed twice a day as they would be at the fish pond, at $9 \mathrm{~h}$ and $14 \mathrm{~h}$. Animals were divided into two groups: control group (A) consisted of 30 specimens in one $100 \mathrm{~L}$ basin and experimental group (B) which was further divided into three $100 \mathrm{~L}$ basins, each of them contained 30 animals. For the first three days, fish were adapted to the new conditions in the basins. Starting from the $4^{\text {th }}$ day, enrofloxacin was administered to the experimental group in a concentration of $10 \mathrm{mg} / \mathrm{kg}$ b.w., i.e. $3 \mathrm{mg}$ per fish. The drug was administered for five days orally twice a day at $9 \mathrm{~h}$ and $14 \mathrm{~h}$. After the drug application, fish were kept in the test basin and if they discharged the drug through the gills they were eliminated from the experiment. From the $6^{\text {th }}$ to the $14^{\text {th }}$ day from the beginning of the treatment, i.e. from the $1^{\text {st }}$ to the $9^{\text {th }}$ day from the end of the treatment, three specimens were sacrificed from the control group and six specimens were sacrificed from the experimental group (2 from each basin). From each fish, dorsal muscle, liver and kidney samples were taken. Samples were frozen and kept at $-20^{\circ} \mathrm{C}$ until laboratory analyses.

Qualitative analysis: microbiological method

Standards were purchased from Sigma company - (USA) enrofloxacin and Bayer - Germany (ciprofloxacin). Test agar pH 8 was inoculated with Escherichia coli ATCC 11303. A working solution of E. coli ATCC 11303 was made with a freshly prepared culture. The culture was diluted in peptone-salt solution to give an optical density of 0.452 at $620 \mathrm{~nm}$ in a $10 \mathrm{~mm}$ cell, with the use of peptone-salt solution as a reference. Sterile petri dishes were filled with inoculated test agar. All the plates were subjected to quality control. Paper disks containing $0.003 \mu \mathrm{g}$ of ciprofloxacin per disk, or $0.006 \mu \mathrm{g}$ of enrofloxacin per disk (Mast diagnostic, Mereyside) were placed in the center of the petri dish. Detection levels of plate $\mathrm{pH}$ 8, E. coli ATCC 11303 were previously determinated (Petrovic et al., 2006): 50 $\mathrm{ng} / \mathrm{g}$ for enrofloxacin and $25 \mathrm{ng} / \mathrm{g}$ for ciprofloxacin. Meat, liver and kidney were frozen at the moment of application. An $8 \mathrm{~mm}$ diameter cork borer was used to remove a cylinder of frozen samples. The meat cylinders were cut into $2 \mathrm{~mm}$ thick disks. Four disks of meat were placed on opposite ends of the plate. Each sample was examined in 12 replicates. The plates were kept refrigerated $\left(4-6^{\circ} \mathrm{C}\right)$ for 2 hours and then incubated at $37^{\circ} \mathrm{C}$ for $24 \mathrm{~h}$.

After incubation the plates were inspected for inhibition zones around the meat disks and average inhibition zone for all 12 replicates was recorded $(2 \mathrm{~mm}$ width was considered positive). 
Quantitative analysis - HPLC with fluorescence detection

Methanol, acetonitrile, $\mathrm{n}$-hexane, and phosphoric acid were purchased from J. T. Baker (Holland). Enrofloxacin and ciprofloxacin analytical standards were purchased from Sigma Company - USA. All the solvents were of HPLC purity.

Liquid chromatography (Ramos et al., 2003) with fluorescence detection at excitation wavelenghth of $280 \mathrm{~nm}$ and emission wavelenghth of $450 \mathrm{~nm}$ was used for the determination of enrofloxacin and ciprofloxacin residues in meat, kidney and liver. Detection limit is $10 \mathrm{ng} / \mathrm{g}$ and quantification limit is $20 \mathrm{ng} / \mathrm{g}$.

Enrofloxacin and ciprofloxacin were isocratically eluted in 7 to 10 minutes. Waters "Sunfire" column, C18, 150x4.6 mm, $3.5 \mu \mathrm{m}$ particle size was used for separation at flow rate of $0.8 \mathrm{~mL} / \mathrm{min}$. The mobile phase $(0.01 \mathrm{M}$ posphoric acid $(\mathrm{pH}=3) /$ acetonitrile; $80: 20 \mathrm{v} / \mathrm{v})$ was used to elute both compounds. Quantification was performed using the external standard method and results were obtained from the calibration curve of blanks fortified at four levels.

Statistical analysis

Statistical analysis was performed by Microsoft Office Excel 2000 and statistical program SPSS for Windows 8.0.0. ANOVA were analyzed by Hadžić (1992). Screening method data were analyzed by the use of descriptive statistical methods. Differences in diameters were analyzed for statistical significance by the use of ANOVA and Student's test. Differences of $p<0.05$ were considered significant.

\section{RESULTS}

Fish tissues (liver, kidney and muscle) were analysed for the presence and quantities of enrofloxacin and ciprofloxacin by the microbiological and HPLC method. The results are shown in Tables 1-2 and Fig. 1-5. All investigation results on the size of the inhibition zone on test-agar $\mathrm{pH}=8$ inoculated with $E$. coli ATCC 11303 were $100 \%$ positive up to the $9^{\text {th }}$ day after the end of treatment. On the $10^{\text {th }}$ day, inhibition zones were determined in two (16.66\%) samples of liver and kidney and in one muscle sample (8.33\%). Inhibition zones decreased in liver from $12.60 \pm 0.46 \mathrm{~mm}$ ( $1^{\text {st }}$ day) to $6.60 \pm 0.61 \mathrm{~mm}$ ( $9^{\text {th }}$ day), in kidney from $9.40 \pm 0.77$ ( $1^{\text {st }}$ day) to $6.20 \pm 0.35 \mathrm{~mm}$ ( $9^{\text {th }}$ day) and in muscle from $9.70 \pm 0.48 \mathrm{~mm}\left(1^{\text {st }}\right.$ day) to $6.05 \pm 0.50 \mathrm{~mm}\left(9^{\text {th }}\right.$ day). Table 1 shows statistical significance of the differences of inhibition zones sizes due to the presence of enrofloxacin residues in analysed tissues. Except for the $7^{\text {th }}$ day from the end of the treatment, size of the inhibition zones was significantly higher $(p \leq 0.01)$ in the liver compared to kidney and muscle tissue.

Figure 1 shows the comparative (liver, kidney and muscle) sizes of the inhibition zones from the $1^{\text {st }}$ to the $10^{\text {th }}$ day after administration of enrofloxacin.

Enrofloxacin residues were quantitatively measured by HPLC method in target tissues from the $1^{\text {st }}$ to the $9^{\text {th }}$ day after the treatment. On the $10^{\text {th }}$ day, concentrations of enrofloxacin were below the quantification limit $(20 \mu \mathrm{g} / \mathrm{kg})$ and on the $11^{\text {th }}$ day, concentrations were below detection limit of the analytical method $(10 \mu \mathrm{g} / \mathrm{kg})$. Enrofloxacin concentrations decreased from the $1^{\text {st }}$ to the $9^{\text {th }}$ 
Acta Veterinaria (Beograd), Vol. 59. No. 5-6, 579-589, 2009.

Đorđević Vesna et al.: Quantitative and qualitative determination

of enrofloxacin residues in fish tissues

day in the liver from $940.91 \pm 9.51 \mu \mathrm{g} / \mathrm{kg}$ to $30.50 \pm 2.08 \mu \mathrm{g} / \mathrm{kg}$, in the kidney from $900.10 \pm 10.65 \mu \mathrm{g} / \mathrm{kg}$ to $38.51 \pm 2.77 \mu \mathrm{g} / \mathrm{kg}$ and in muscle from $822.88 \pm$ $12.38 \mu \mathrm{g} / \mathrm{kg}$ to $34.68 \pm 2.84 \mu \mathrm{g} / \mathrm{kg}$ (Table 2). Ciprofloxacin was not determined in the investigated samples.

Table 1. Comparative view of residues determination by microbiological method in fish tissues after treatment (inhibition zone in $\mathrm{mm}$ )

\begin{tabular}{|c|c|c|c|}
\hline \multirow{2}{*}{$\begin{array}{c}\text { Days after } \\
\text { treatment }\end{array}$} & \multicolumn{3}{|c|}{ Tissue } \\
\cline { 2 - 4 } & $\begin{array}{c}\text { Liver } \\
\mathrm{x} \pm \text { Sd }\end{array}$ & $\begin{array}{c}\text { Kidney } \\
\mathrm{x} \pm \text { Sd }\end{array}$ & $\begin{array}{c}\text { Muscle } \\
\mathrm{x} \pm \text { Sd }\end{array}$ \\
\hline \hline $1^{\star \star \star}$ & $12.60 \pm 0.46^{\mathrm{x}}$ & $9.40 \pm 0.77^{\mathrm{y}}$ & $9.70 \pm 0.48^{\mathrm{y}}$ \\
\hline 2 & $10.70 \pm 0.48^{\mathrm{x}}$ & $9.70 \pm 0.35^{\mathrm{y}}$ & $9.50 \pm 0.33^{\mathrm{y}}$ \\
\hline 3 & $8.60 \pm 0.46^{\mathrm{x}}$ & $8.20 \pm 0.54^{\mathrm{x}}$ & $7.10 \pm 0.46^{\mathrm{y}}$ \\
\hline 4 & $8.80 \pm 0.42^{\mathrm{x}}$ & $7.95 \pm 0.37^{\mathrm{y}}$ & $7.70 \pm 0.35^{\mathrm{y}}$ \\
\hline 5 & $9.85 \pm 0.58^{\mathrm{x}}$ & $7.65 \pm 0.34^{\mathrm{y}}$ & $8.30 \pm 0.48^{\mathrm{y}}$ \\
\hline 6 & $7.40 \pm 0.66^{\mathrm{x}}$ & $6.70 \pm 0.54^{\mathrm{y}}$ & $7.48 \pm 0.39^{\mathrm{x}}$ \\
\hline 7 & $6.65 \pm 0.53^{\mathrm{x}}$ & $7.65 \pm 0.41^{\mathrm{y}}$ & $7.65 \pm 0.41^{\mathrm{y}}$ \\
\hline 8 & $7.70 \pm 0.63^{\mathrm{x}}$ & $5.85 \pm 0.58^{\mathrm{y}, \mathrm{a}}$ & $6.50 \pm 0.41^{\mathrm{y}} \mathrm{b}$ \\
\hline $9^{\star \star \star}$ & $6.60 \pm 0.61^{\mathrm{a}}$ & $6.20 \pm 0.35^{\mathrm{y}}$ & $6.05 \pm 0.50^{\mathrm{b}}$ \\
\hline 10 & $2.50^{\star}$ & $2.50^{\star}$ & $2.00^{\star \star}$ \\
\hline 11 & - & - & - \\
\hline
\end{tabular}

Note: *16.66 \% positive samples; **8.33\% positive samples; ***1-9 $100 \%$ positive samples

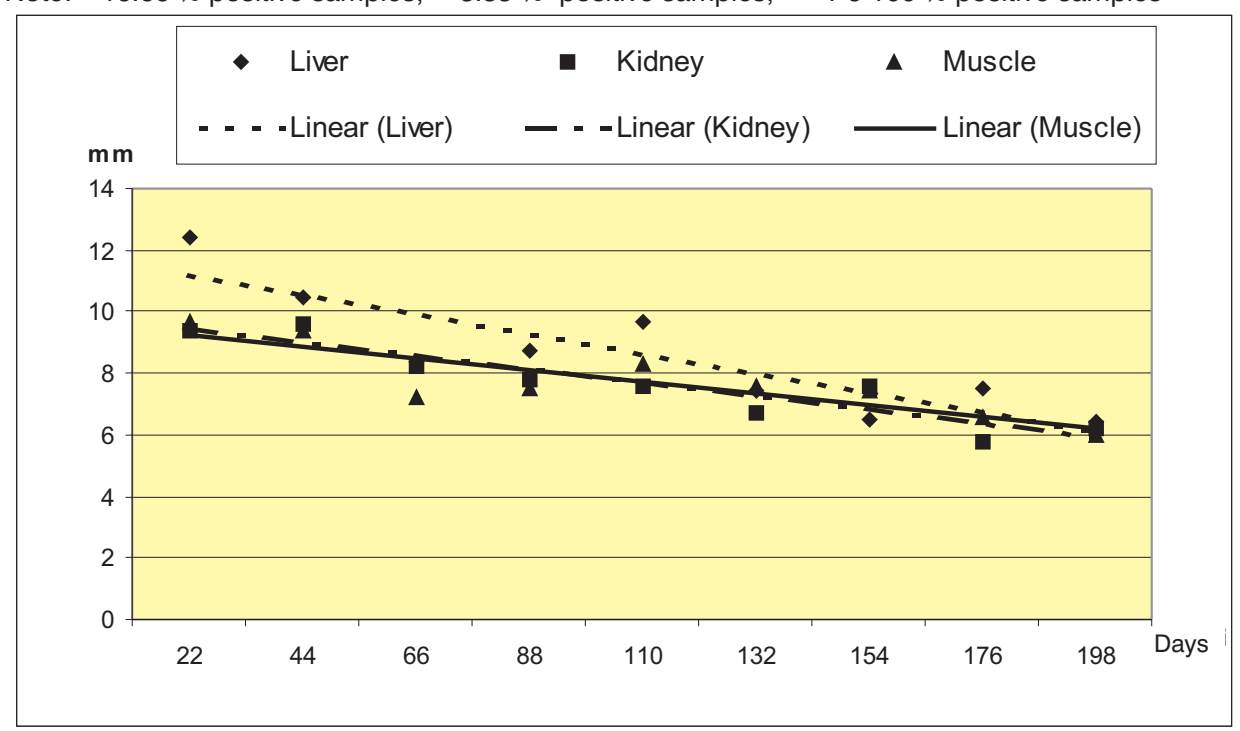

Figure 1. Comparative view of inhibition zones decrease on test-agar, in fish tissues after the end of the treatment 
Concentration of enrofloxacin below MRL $(200 \mathrm{~g} / \mathrm{kg})$ was determined in liver samples on the $6^{\text {th }}$ day and in kidney on the $7^{\text {th }}$ day after the treatment. Muscle tissue contained enrofloxacin below MRL $(100 \mu \mathrm{g} / \mathrm{kg})$ on the $9^{\text {th }}$ day after the treatment. Decrease of enrofloxacin levels from the $1^{\text {st }}$ to the $9^{\text {th }}$ day is shown in Figure 2.

Table 2. Residues of enrofloxacin $(\mu \mathrm{g} / \mathrm{kg})$ in fish tissues determined by HPLC method

\begin{tabular}{|c|c|c|c|}
\hline \multirow{2}{*}{$\begin{array}{c}\text { Days after } \\
\text { treatment }\end{array}$} & $\begin{array}{c}\text { Liver } \\
\mathrm{x} \pm \text { Sd }\end{array}$ & $\begin{array}{c}\text { Kidney } \\
\mathrm{x} \pm \text { Sd }\end{array}$ & $\begin{array}{c}\text { Muscle } \\
\mathrm{x} \pm \text { Sd }\end{array}$ \\
\cline { 2 - 4 } & $940.91 \pm 9.51^{\mathrm{x}}$ & $900.10 \pm 10.65^{\mathrm{y}}$ & $822.88 \pm 12.38^{\mathrm{z}}$ \\
\hline \hline $1^{\star \star \star}$ & $766.61 \pm 9.92^{\mathrm{x}}$ & $770.38 \pm 1.80^{\mathrm{y}}$ & $773.43 \pm 6.25^{\mathrm{z}}$ \\
\hline 2 & $276.30 \pm 6.00^{\mathrm{x}}$ & $500.33 \pm 8.84^{\mathrm{y}}$ & $647.21 \pm 9.42^{\mathrm{z}}$ \\
\hline 3 & $151.91 \pm 7.74^{\mathrm{x}}$ & $250.66 \pm 7.88^{\mathrm{y}}$ & $361.73 \pm 8.75^{\mathrm{z}}$ \\
\hline 4 & $246.48 \pm 9.33^{\mathrm{x}}$ & $289.84 \pm 10.10^{\mathrm{y}}$ & $306.68 \pm 7.46^{\mathrm{z}}$ \\
\hline 5 & $198.66 \pm 7.76^{\mathrm{x}}$ & $227.55 \pm 7.57^{\mathrm{y}}$ & $197.65 \pm 8.05^{\mathrm{z}}$ \\
\hline 6 & $91.67 \pm 7.71^{\mathrm{x}}$ & $183.41 \pm 7.82^{\mathrm{y}}$ & $234.34 \pm 8.50^{\mathrm{z}}$ \\
\hline 7 & $106.52 \pm 9.00^{\mathrm{x}}$ & $134.58 \pm 7.44^{\mathrm{y}}$ & $172.71 \pm 7.79^{\mathrm{z}}$ \\
\hline 8 & $30.50 \pm 8.89^{\mathrm{x}}$ & $38.51 \pm 2.77^{\mathrm{y}}$ & $34.68 \pm 2.84^{\mathrm{z}}$ \\
\hline $9^{\star \star \star}$ & $>20$ & $>20$ & $>20$ \\
\hline 10 & - & - & - \\
\hline $11^{\star}$ & \multicolumn{3}{c}{} \\
\hline
\end{tabular}

* below detection limit

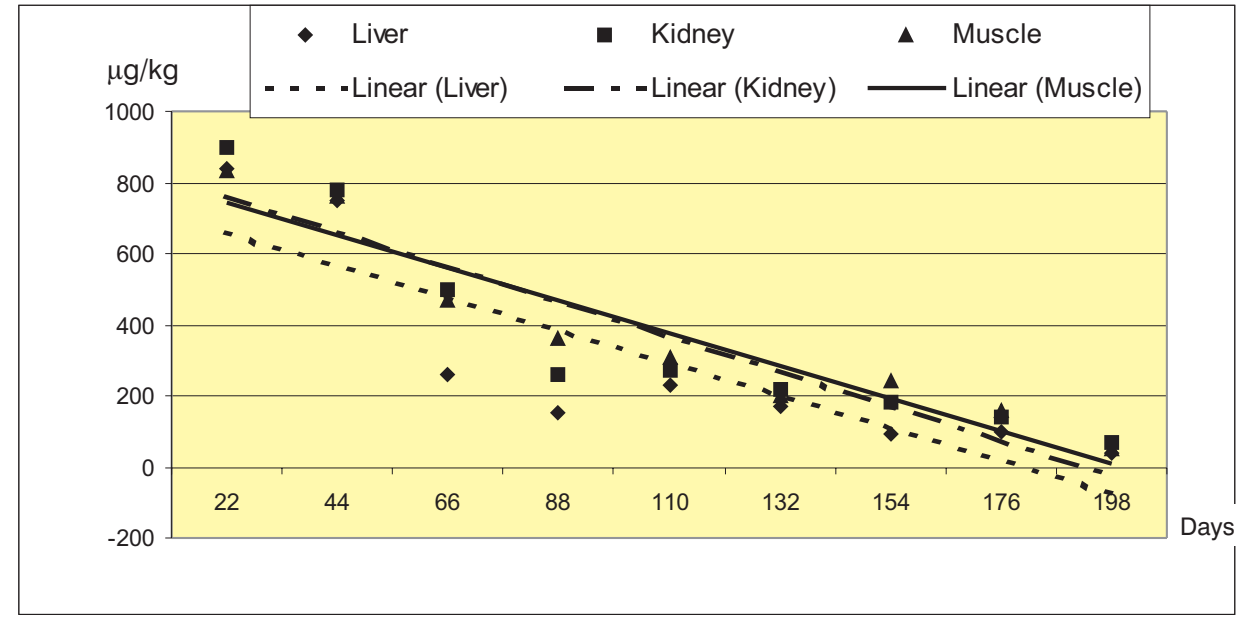

Figure 2. Comparative view of decrease of enrofloxacin content in fish tissues after the end of treatment

Figure 3 shows the chromatogram of enrofloxacin standard solution, Figures 4, 5 and 6 show chromatograms of enrofloxacin residues findings in fish tissues (liver, muscle, kidney). 
Acta Veterinaria (Beograd), Vol. 59. No. 5-6, 579-589, 2009.

Đorđević Vesna et al: Quantitative and qualitative determination

of enrofloxacin residues in fish tissues

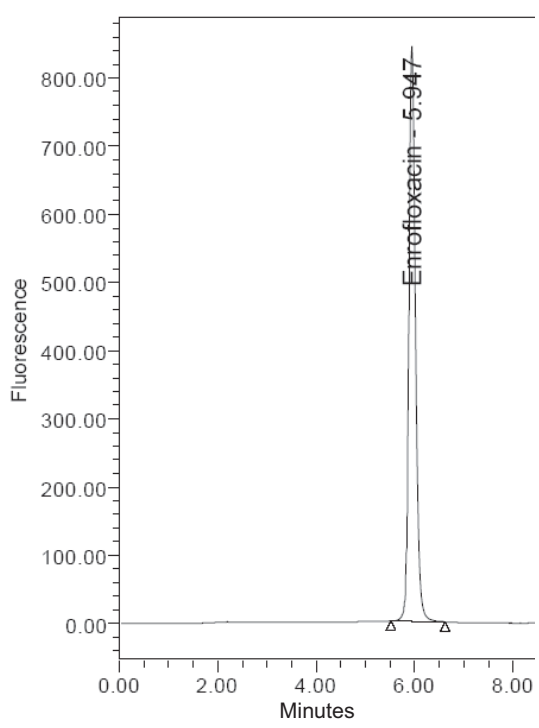

Figure 3. Chromatogram of enrofloxacin standard

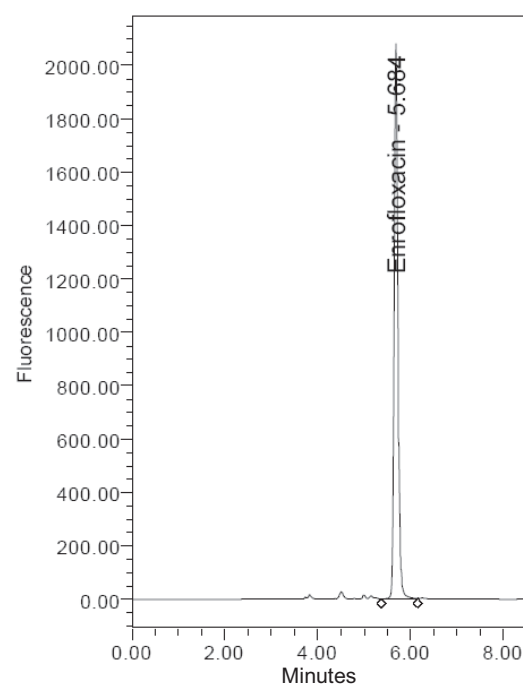

Figure 5. Chromatogram of enrofloxacin residues in fish muscle on the $1^{\text {st }}$ day after treatment

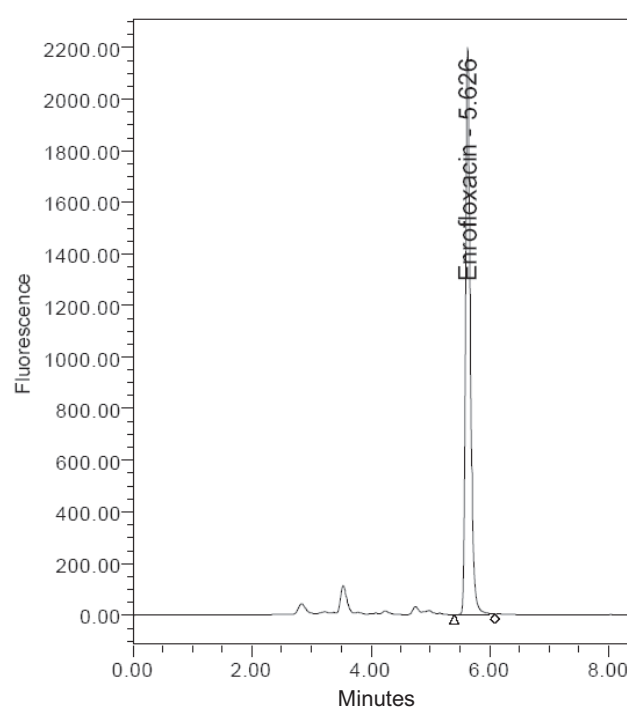

Figure 4. Chromatogram of enrofloxacin residues in fish liver on the $1^{\text {st }}$ day after treatment

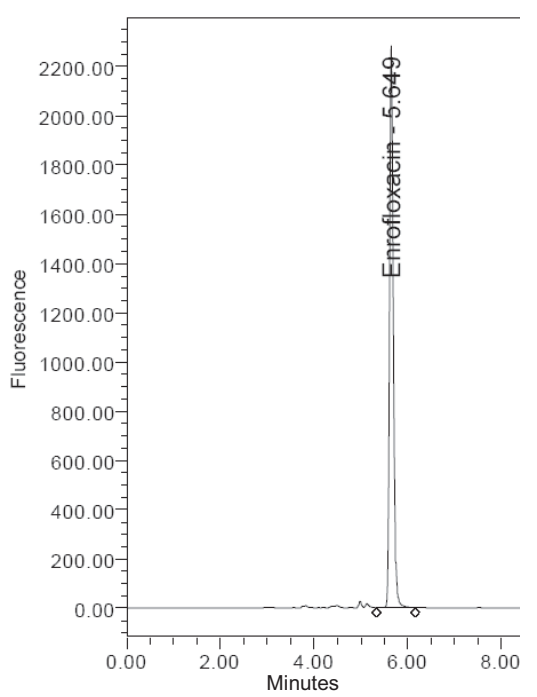

Figure 6. Chromatogram of enrofloxacin residues in fish kidney on the $1^{\text {st }}$ day after treatment 


\section{DISCUSSION}

Enrofloxacin is an antimicrobial agent developed in the late 1980s exclusively for use in veterinary medicine. Enrofloxacin $\mathrm{C} 19 \mathrm{H} 42 \mathrm{FO} 3$ or (1cyclopropyl-6 fluoro-1,4-dihidro-4 oxo-7 (4-ethyl-1 piperazinyl 3 - quinoline carboxylic acid) is a fluroquinolone antibiotic which acts by inhibition of bacterial DNA- gyrase, and which has bactericidal activity against Enterobacteriaceae and other gram-negative bacteria and has some activity against certain gram positive cocci (Martindale, 2005., Martinez et al., 2005). During the last few years, enrofloxacin has received growing attention because of its potential efficiency in the threatment of disease in fish (Burka et al., 1997; Della Rocca et al., 2004; Lucchetti et al., 2004). In mammalian and nonmammalian species, enrofloxacin is metabolysed to ciprofloxacin, a metobolite that contributes to the activity of enrofloxacin and which is itself a potent antimicrobal agent. Some microbiological, metabolic and pharmacokinetic aspects of enrofloxacin have been reported from previous studies (Bowser et al., 1992; Lewbart et al., 1997; Intorre et al., 2000).

From the studies stated above, it can be concluded that numerous factors have an influence on the pharmacokinetics of enrofloxacin such as route of administration (parenteral, oral, in water), fish species, water temperature, length of therapy, therapeutic dose etc. This is the main reason why data on persistance of residues of enrofloxacin and its metabolites (especially ciprofloxacin) are difficult to compare. Therefore, it is hard to determine the withdrawal period and pharmaceutical companies do not specify the withdrawal period for enrofloxacin in fish treatment (Luccheti et al., 2004).

Commission Directive (EEC) No 22/2001 (EEC 2001) provides a minimum withdrawal period of $500{ }^{\circ} \mathrm{C}$ - day for any type of product that is administered offlabel and for which no other information is available.

According to our data, on the first day after treatment, the highest concentration of enrofloxacin was found in liver $(940.91 \pm 9.51 \mu \mathrm{g} / \mathrm{kg})$, then in kidney and muscle $(900.10 \pm 10.65 \mu \mathrm{g} / \mathrm{kg})$ samples. Although the differences in concentration of enrofloxacin are statistically significant $(p<0.01)$, they are not as evident as is the case with enrofloxacin distribution in the tissues of broiler chicken.

Petrovic et al. (2006) determined that on the 1st day after treatment, enrofloxacin concentration in liver samples was 2.07 times higher then in the breast muscle of broilers. On the 1st day after treatment the presence of ciprofloxacin was not determined in the analysed fish tissues. Our results show that enrofloxacin content in liver sharply decreases after the 2nd day of treatment, and in the kidney and muscle after the 3rd day (Table 2, Figure 2). Enrofloxacin concentration below MRL $(200 \mu \mathrm{g} / \mathrm{kg})$ was determined in the liver 6 days after treatment and in the kidney 7 days after treatment. In muscle tissue, enrofloxacin concentration was lower than MRL $(100 \mu \mathrm{g} / \mathrm{kg})$ on the 8th day after treatment.

According to the results obtained by Lucchetti et al. (2004), ciprofloxacin was not determined in trout tissue in $265^{\circ} \mathrm{C} /$ days. Enrofloxacin concentration was constant up to $26.50{ }^{\circ} \mathrm{C} /$ days and then it plummeted down to $265^{\circ} \mathrm{C} /$ days. 
Further concentration decrease in fish muscle was very slow and at $708^{\circ} \mathrm{C} /$ days enrofloxacin concentration was below MRL (Steffenak et al., 1991).

In the previous study (Steffenak et al., 1991) in which salmon in seawater at a temperature of $6^{\circ} \mathrm{C}$ were treated with enrofloxacin at $10 \mathrm{mg} / \mathrm{kg}$ for 10 days, muscle tissue contained $6 \mu \mathrm{g}$ of drug per $\mathrm{kg} 60$ days after the end of the treatment.

The results of Lucchetti et al. (2004) show that after 59 days the concentration of enrofloxacin in trout muscle treated with the same dose of the drug while kept in water with an average temperature of $13.3^{\circ} \mathrm{C}$ was $100 \mu \mathrm{g} / \mathrm{kg}$.

We can conclude from these results that elimination of enrofloxacin was less rapid in trout compared to salmon and even less in carp. This shows that the elimination of the drug from fish tissues depends not only on water temperature, but also on fish species which was also determined in the case of flumequine (Malvisi et al., 1997).

Studies on the pharmacokinetics of enrofloxacin in a variety of fish species, mainly salmonids, treated by the oral or the parenteral route at doses ranging from 5 to $50 \mathrm{mg} / \mathrm{kg}$ have been published (Intorre et al., 2000; Lewbart et al., 1997; Lucchetti et al., 2004). In contrast, very few studies on pharmacokinetics of quinolones in fishes treated with multiple doses of medicated feed and reared under field conditions have been carried out (Malvisi et al., 1997; Tyrpenou et al., 2003).

Results of the screening method are manifested by the presence of inhibition zone, which is proportional to the quantity of antibiotics in samples (liver, kidney, muscle). Therefore, the results of the screening method are not only qualitative but also semiquantitative.

The results show that the sizes of inhibition zones are different depending on tested tissue and that the zones decrease from the 1st to the 9th day after treatment (Table 1, Fig. 1). Inhibition zones are larger in liver than in kidney and muscle samples which is the consequence of the higher concentrations of enrofloxacin in the liver. This was confirmed by HPLC method. We also observed a certain irregularity in the decrease of enrofloxacin concentration in investigated tissues which can be explained by the imbalance in fish weight, therefore the differences in the quantity of administered drug per weight unit, as well as by the differences in the quantity of taken feed.

\section{CONCLUSIONS}

1. After the 5-day oral treatment of carps, enrofloxacin residues in tissues were determined up to the 10th day after the end of the drug application.

2. Enrofloxacin content determined by the HPLC method was lower than $\mathrm{MRL}$; drug residues were determined in liver on the 6th day after treatment, in kidney on the 7th day and in muscle on the 9th day after treatment.

3 . The results of enrofloxacin residues determination by screening method on the medium with E. Coli ATCC 11303, pH8 show that this procedure can be used for qualitative determination of enrofloxacin. Screening method allows determination of enrofloxacin in fish tissues below the MRL. 
Address for correspondence:

Mr Vesna Đorđević,

Institute of Meat Higiene and Tehnology,

Kaćanskog 13

11000 Belgrade

Serbia

E-mail: vesnazdjordjevic@gmail.com

\section{REFERENCES}

1. Alderman DJ, 1988, Fisheries chemotherapy: a review, In JF Muir and RJ Rberts (ed.), Recent advances in aquaculture. Timber Press, Portland, Oreg, 28-33.

2. Baggot JD, 1977, Principles of drug disposition in domestic animals: the basis of veterinary clinical pharmacology. The WB Saunders Co., Philadelphia.

3. Bowser PR, House M, 1990. In vitro sensitivity of some fish patogens to the quinolones nalidixic acid and oxolonic acid and the fluoroquinolone enrofloxacin, Bull Eur Assoc Fish Pathol, 10, 48-9.

4. Bowser PR, Wooster GA, Leger J, Babish JG, 1992, Pharmacokinetics of enrofloxacin in fingerling rainbow trout (Oncorhynchus mykiss), J Vet Pharmacol Ther, 15, 62-71.

5. Boxall AB, Fogg LC, Blackwell PA, Kay P, Pemberton EJ, Croxford A, 2004, Veterinary medicines in the enviroment, Rev Environ Contam Toxicol, 180, 1-91.

6. Bragg JF, Todd JM, 1988, In vitro sensitivity to Baytril of some bacteria pathogenic to fish, Bull Eur Assoc Fish Pathol, 8, 5-6.

7. Brown SA, 1996, Fluoroquinolones in animal health, J Vet Pharmacol Ther, 19, 1-14.

8. Burka JF, Hammel KL, Horsberg TE, Johnson GR, Rainnie DJ, Spear DJ, 1997, Drugs in salmonid aquaculture - a review, J Vet Pharmacol Ther, 20, 333-49.

9. Dalsgaad, Bjerregaard J, 1991, Enrofloxacin as an antibiotic in fish, Acta Vet Scand, 87, 300-3.

10. Lucchetti D, Fabrizi L, Guandalini E, Podesta E, Marvasi L, Zaghini A et al., 2004, Long Depletion Time of Enrofloksacin in Rainbow Trout (Oncorhynchus mykiss), Antimicrob Agents Chemoth, 48, 10, 3912-7.

11. Della Rocca G, Di Salvo A, Malvisi J, Sello M, 2004, The disposition of enrofloxacin in seabream (Sparus aurata L) after single intravenous injection or from medicated feed administration, Aquaculture, 232, 1-4, 53-62.

12. Drlica K, 1999, Mechanism of fluoroquinolone action, Curr Opin Microbiol, 2, 504-8.

13. European Economic Commission, 2002, Commission Regulation (EEC) No. 1181/2002. Regulation of 1 July 2002. amending Annex I of Council Regulation (EEC) No. 2377/90, laying down a Community procedure for the establishment of maximum residue limits of veterinary medicinal products in foodstuffs of animal orgin. In Official Journal of the European Communities, No. L.172/13. European Economic Commission, Brissels, Belgium.

14. Cabello FC, 2006, Heavy use of prophylatic antibiotics in aquaculture: a growing problem for human and animal health and for the environment, Environ Microbiol, 8, 7, 1137-44.

15. Hadžić O, 1992, Disperziona analiza, U: Hadžić O, urednik, Numeričke i statističke metode u obradi eksperimentalnih podataka, Drugo izdanje, Novi Sad, Institut za matematiku, Štamparija za graf. delatnost, 194-206.

16. Ihrke PJ, Papich MG, Demanuelle TC, 1999, The use of fluoroquinolones in veterinary dermatology, Vet Dermatol, 10, 193-204 [CrossRef].

17. Intorre L, S Cecchini S Bertini AM, Cognetti Varriale, Soldani G, Mengozzi G, 2000 , Pharmacokinetics of enrofloxacin in the seabass (Dicentrarchus labrax), Aquaculture, 182, 4959.

18. Lewbart G, S Vaden J Deen, Manaugh C, Whitt D, Doi A et al., 1997, Pharmacokinetics of enrofloxacin in the red pacu (Colossoma brachypomum) after intramuscolar, oral and bath administration, $J$ Vet Pharmacol Ther, 20, 124-8.

19. Malvisi J, della Rocca G, Anfossi P, Giorgetti G, 1997, Tissue distribution and depletion of flumequine after in-feed administration in sea bream (Sparus aurata). Aquaculture, 157, 197204 [CrossRef]. 
20. Martindale, 2005, In: Sweetman S, editor, The Complete Drug Reference, Thirty fourth edition, London: Pharmaceutical Press.

21. Martinez M, Mc Dermott P, Walker R, 2005, Pharmacology of the fluoroquinolones: a perspective for the use in domestic animals, Vet $J$, in press.

22. Martinses $B$, Horsberg TE, 1995, Comparative single dose pharmacokinetics of four quinolones, oxolinic acid, flumeguine, sarafloxacin, and enrofloxacin, in Atlantic salmon (Solmon Salar) held in seawater at $10^{\circ} \mathrm{C}$, Antimicrob Agents Chemoth, 39, 1059-64.

23. Petrović Jelena, Baltić M, Ćupić V, Stefanović S, Stojanović Dragica, 2006. Residues of enrofloxacin and its main metabolite ciprofloxacin in broiler chickens, Acta Veterinaria, 56, 5-6, 497-506.

24. Ramos M, Aranda A, Gracia E, Reuvers T, Hooghis H, 2003, Simple and sensitive determination of five quinolones in food by liquid chromatography with fluorescence detection, $J$ Chromatography $B, 789,2$, 373-81.

25. Schneider MJ, Donoghue DJ, 2002, Multiresidue analysis of fluoroquinolone antibiotics in chicken tissue using liquid chromatography-fluorescence-multiple mass spectrometry, $J$ Chromatography B, 780, 1, 83-92.

26. STAR PROTOCOL Laboratorie d'etudes et de recherches sur les medicaments veterinaires et les desinfectants; Community Reference Laboratory, april 2005.

27. Steffenak I, Hormazabal V, Yndestad M, 1991, Reservoir of quinolone residues in fish, Food Add Contamin, 8, 777-80.

28. Stoffegren DA, Wooster GA, Bustos PS, Bowser PR, Babish JG, 1997, Multiple route and dose pharmacokinetics of enrofloxacin in juvenile Antlatic salmon, J Vet Pharmacol Ther, 20, 111-23.

29. Tandriole VT, 1998, The quinolones, 262. Academic Press, London, United Kingdom.

30. Tyrpenou AE, Kotzamanis YP, Alexis MN, 2003, Flumequine depletion from muscle plus skin tissue of gilthead seabream (Sparus aurata $\mathrm{L}$ ) fed flumequine medicated feed in seawater at 18 and $24^{\circ} \mathrm{C}$. Aquaculture, 220, 633-42 [CrossRef].

\title{
KVANTITATIVNO I KVALITATIVNO ODREĐIVANJE ENROFLOKSACINA U TKIVIMA RIBA
}

\author{
ĐORĐEVIĆ VESNA, BALTIĆ M, ĆIRKOVIĆ M, KILIBARDA NATAŠA, \\ GLAMOČLIJA NATAŠA, STEFANOVIĆ S i MIŠČEVIĆ MIRJANA
}

\section{SADRŽAJ}

Prisustvo rezidua enrofloksacina u jetri, bubregu i mesu riba ispitano je posle njegovog peroralnog aplikovanja. Za ispitivanje rezidua su korišćene: mikrobiološka metoda - ploča pH 8 sa Escherichia coli ATTC 11303 i HPLC metoda sa flurescentnom detekcijom. Posle petodnevne oralne terapije šarana rezidue enrofloksacina u tkivima riba su dokazane i devetog dana po prestanku terapije. Sadržaj enrofloksacina dokazan HPLC postupkom, niži od MRL vrednosti, u jetri je dokazan šestog dana po prestanku terapije, u bubregu sedmog dana a u mišićnom tkivu devetog dana po prestanku terapije. Rezultati utvrđivanja rezidua enrofloksacina skrining postupkom na podlozi pH 8 E.coli ATCC 11303 pokazuju da se ovaj postupak može koristiti za kvantitativno dokazivanje enrofloksacina. Skrining postupkom u tkivima riba mogu da se dokažu količine enrofloksacina ispod MRL vrednosti. Ciprofloksacin nije utvrđen u jetri, bubrezima i mesu riba. 